\title{
MARACATU RURAL: UMA REPRESENTAÇÃO DA CULTURA POPULAR PERNAMBUCANA? RURAL MARACATU: A REPRESENTATION OF PERNAMBUCANA CULTURE?
}

\author{
Adriano Carlos de MOURA \\ IFPE - Campus Recife \\ adrianocmoura@bol.com.br
}

\begin{abstract}
RESUMO. Neste artigo, buscamos fazer um resgate histórico das origens, bem como das relações interculturais presentes no Maracatu Rural ou de Baque Solto, da Zona da Mata de Pernambuco, estabelecidas com outros folguedos da cultura popular pernambucana, a exemplo do cambinda, do bumba meu boi, do cavalo-marinho e, sobretudo, do Maracatu Nação ou de Baque Virado. Tomando como fundamento de que só se pode caracterizar ou definir uma cultura por oposição às demais (RASTIER,2015), no caso específico dos maracatus, defendemos que o de baque solto não pode ser concebido como uma variante do maracatu nação, mas como produto de uma complexa combinação de fatores. Sua dança, sua música, seus atores, seus temas e figuras são representativos de um riquíssimo amálgama das mais diversas manifestações culturais, permitindo caracterizá-lo como de cultura cosmopolita. e não, apenas, representativo da cultura popular do estado de Pernambuco.
\end{abstract}

Palavras-chave: Maracatu Rural. Cultural Popular. Interculturalidade.

ABSTRACT. In this article, we seek to make a historical rescue of the origins of Maracatu Rural, as well as intercultural relations present between Maracatu Rural or Maracatu de Baque Solto, from Pernambuco, Brazil, and other popular folkloric styles of that Brazilian state, such as Bumba meu boi, the Cavalo-marinho and, above all, Maracatu Nação or Maracatu de Baque Virado. We consider that one can only characterize or define one culture in opposition to the others and, in the pecific case of maracatus, we argue that the Maracatu de Baque Solto can not be conceived as a variant of the Maracatu Nação, but as the product of a complex combination of factors. Its dance, its music, its actors, its themes and figures are representative of a rich amalgam of the most diverse cultural manifestations of Pernambuco. This multicultural character of Maracatu Rural is precisely what makes it so representative of the popular culture of the state of Pernambuco.

Keywords: Maracatu Rural. Popular Culture. Interculturality.

\section{Introdução}

Considerando o parecer de François Rastier (2015: p.17) de que uma cultura só pode ser compreendida do ponto de vista cosmopolita ou intercultural, realizamos, neste artigo, um resgate histórico das origens do Maracatu Rural ou de Baque solto e das relações interculturais que aquele estabelece com outros folguedos da cultura popular pernambucana e brasileira, a exemplo do cambinda, do bumba meu boi, do cavalo-marinho e, sobretudo, do Maracatu Nação ou de Baque Virado. Intencionávamos descobrir até que ponto poderíamos afirmar, 
como se costuma dizer corriqueiramente, que o Maracatu de Baque Solto é a mais genuína expressão da Cultura Popular Pernambucana

Lembra, ainda, Rastier (2015: p.16-17) que "uma cultura se define como um ponto de vista sobre outras culturas e não por uma auto contemplação identitária coletiva." Para caracterizar as Ciências da cultura (entre as quais, inclui as ciências folclóricas) autor propõe (id. Ib p. 17.) diferenciá-las e compará-las porque:

[...] para cada uma, é o conjunto das outras culturas contemporâneas e passadas que desempenha o papel de corpus. Com efeito, uma cultura não é uma totalidade, mas se forma, evolui e desaparece nas trocas e nos conflitos com as outras. Também, as culturas só podem ser descritas diferencialmente com os objetos culturais que as compõem, em primeiro lugar, as línguas e os textos (2015: p. 17).

\section{As origens do carnaval no Brasil e em Pernambuco}

Mesmo sendo considerado, no século XIX, como algo não civilizado e brutal, o Entrudo foi, durante muito tempo, a brincadeira carnavalesca mais popular em território brasileiro. Sobre tal popularidade assumida por esse jogo, Ferreira (2004, p. 74) reforça que, nas principais cidades brasileiras,

[...] seja em Porto Alegre, Florianópolis, Salvador, Fortaleza, Recife, São Paulo ou Rio de Janeiro, o costume de se lançar águas, pós de todos os tipos, cinzas, líquidos imundos ou perfumes sobre quem passasse por perto tomava conta de boa parte da sociedade nos três dias dedicados às brincadeiras.

O costume do jogo do Entrudo chegou ao Brasil junto com os nossos primeiros colonizadores portugueses. Silva (1997) afirma que a primeira menção do termo Entrudo, do latim introitus, que quer dizer "entrada", ocorre nas "Denunciações do Santo Ofício em Pernambuco".

No referido texto, há um depoimento datado de 10 de novembro de 1593, em que um senhor chamado Diogo Gonçalves afirma que, em 1553, os cristãosnovos e proprietários do Engenho Camarajibe, Diogo Fernandes e Branca Dias, teriam ofertado "numa terça-feira de entrudo" algumas tainhas secas aos seus funcionários, o que, por si só, não seria considerado nenhum pecado pelo Santo Ofício.

Entretanto, no outro dia, uma quarta-feira de cinzas, o casal teria oferecido aos mesmos funcionários como almoço uma grande porca gorda, desrespeitando completamente os princípios quaresmais de abstinência. 
A referência à terça-feira de entrudo faz-nos crer que comemorações entrudísticas ou carnavalescas já ocorriam no Brasil desde o início do período colonial. Queiroz (1992), inclusive, afirma que a festa carnavalesca:

[...] chegou ao continente sul-americano nas caravelas dos colonizadores; no Brasil, ela foi constantemente marcada por contribuições culturais sucessivas provenientes da Europa, os elementos africanos se lhe juntaram recentemente (QUEIROZ, 1992, p. 29).

Brincadeiras semelhantes ao que conhecemos como Entrudo perduraram no Brasil nos séculos seguintes. O historiador britânico Henry Koster (1942) relata que presenciou, em 1815, um Entrudo na Ilha de Itamaracá, estado de Pernambuco. Ele descreve que as brincadeiras do Entrudo iam desde a simulação de uma batalha entre mouros e cristãos, após as quais os primeiros eram batizados, ao lançamento de líquidos ou pós sobre os transeuntes.

É importante que se diga que havia dois tipos de Entrudo: o familiar e o popular. O Entrudo familiar ocorria no interior das residências e consistia na fabricação de bolas de cera cheias de líquidos aromatizados, conhecidas como "limões de cheiro", que eram jogados nos familiares e nos convidados à casa.

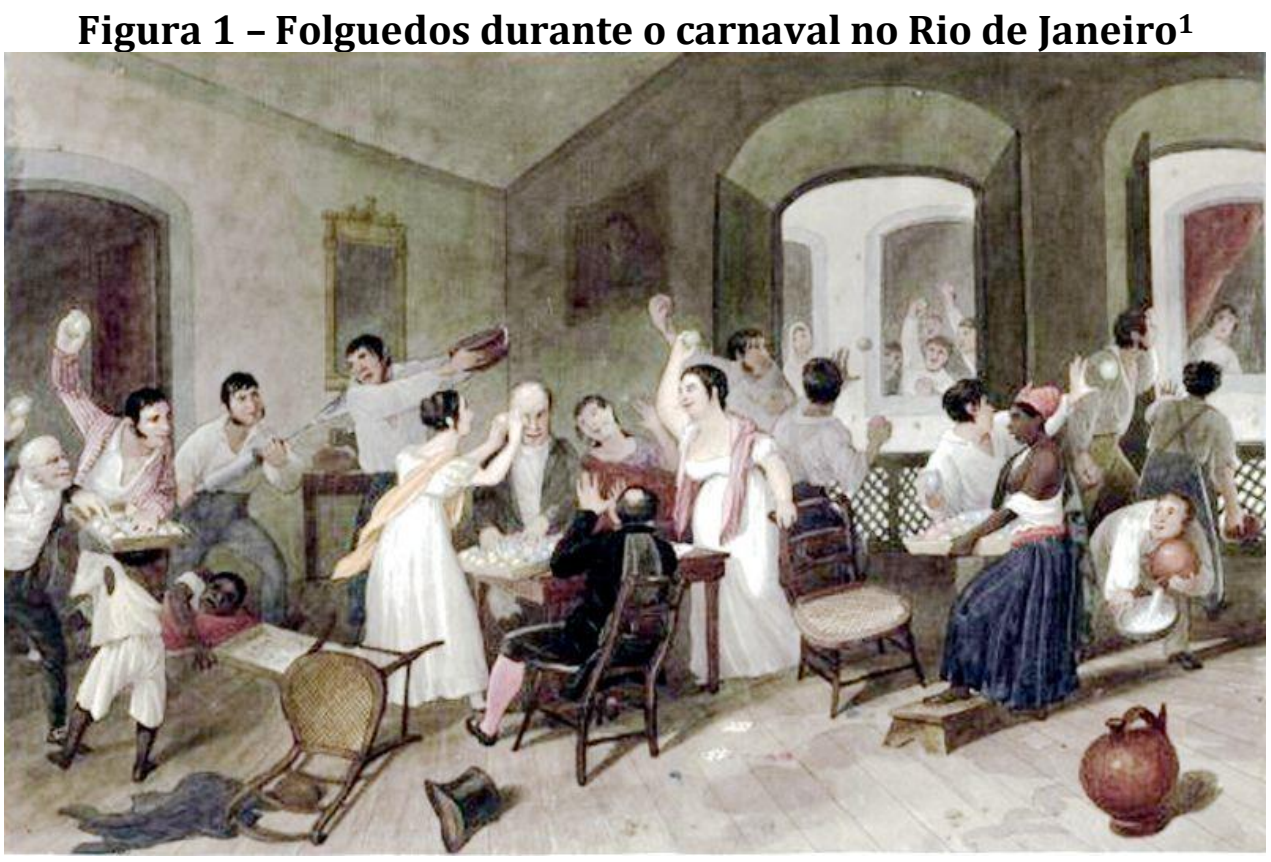

${ }^{1}$ EARLE, Augustus. Folguedos durante o entrudo no Rio de Janeiro. 1822-1823. 1 original de arte, aquarela, $21,6 \mathrm{~cm}$ x $34 \mathrm{~cm}$. National Library of Australia. Disponível em: http://pt.wikipedia.org/wiki/Ficheiro:Games during the carnival at Rio de_Janeiro.jpg.

Acesso em: 23 set. 2013. 
Era muito comum uma jovem tomar a iniciativa de jogar esses projéteis naquele rapaz que a interessava, pois o Entrudo familiar era uma ótima oportunidade de socialização entre os membros das famílias abastadas do Brasil colonial.

Porém, quem mais sofria com as troças entrudísticas eram os estrangeiros e os escravos, vítimas preferidas das molhadeiras e enfarinhamentos. Aqueles, por seu desconhecimento da festa; e estes, pela submissão aos seus senhores.

Vale salientar que nem sempre era tão clara a divisão entre Entrudo Popular e Familiar. Como se vê na pintura de Augustus Earle, na Figura 1, muitos moradores ficavam, à espreita nas janelas, esperando alguém passar na rua para atacá-lo com alguma laranjinha ou limão de cera, com uma bisnaga cheia com algum líquido, com pós de todo tipo ou com baldes cheios d’água.

O Entrudo popular ou de rua era muito mais barulhento e selvagem. As ruas eram tomadas pelos escravos, negros libertos e, empregados, em suma, pelos membros da pobreza. 0 fato de as famílias ricas se reclusarem em seus lares para brincarem uma forma de Entrudo mais branda, dava a impressão de que as classes subalternas tomava conta da cidade.

Esse tipo de Entrudo praticado pelas classes subalternas era muito mais espontâneo e, muitas vezes, violento. Qualquer coisa que estivesse à mão era utilizada como munição: alvaiade (derivado de chumbos usado na pintura), vermelhão ou pó de sapato, areia, água suja da sarjeta, restos de comida etc.

Os membros da sociedade evitavam sair às ruas naqueles dias, pois, embora fosse claro que um escravo não se atreveria a lambuzar um homem branco, era possível que os líquidos fétidos utilizados no Entrudo respingassem em quem se atrevesse a cruzar as vias públicas. 
Figura 2 - Cena de carnaval ${ }^{2}$

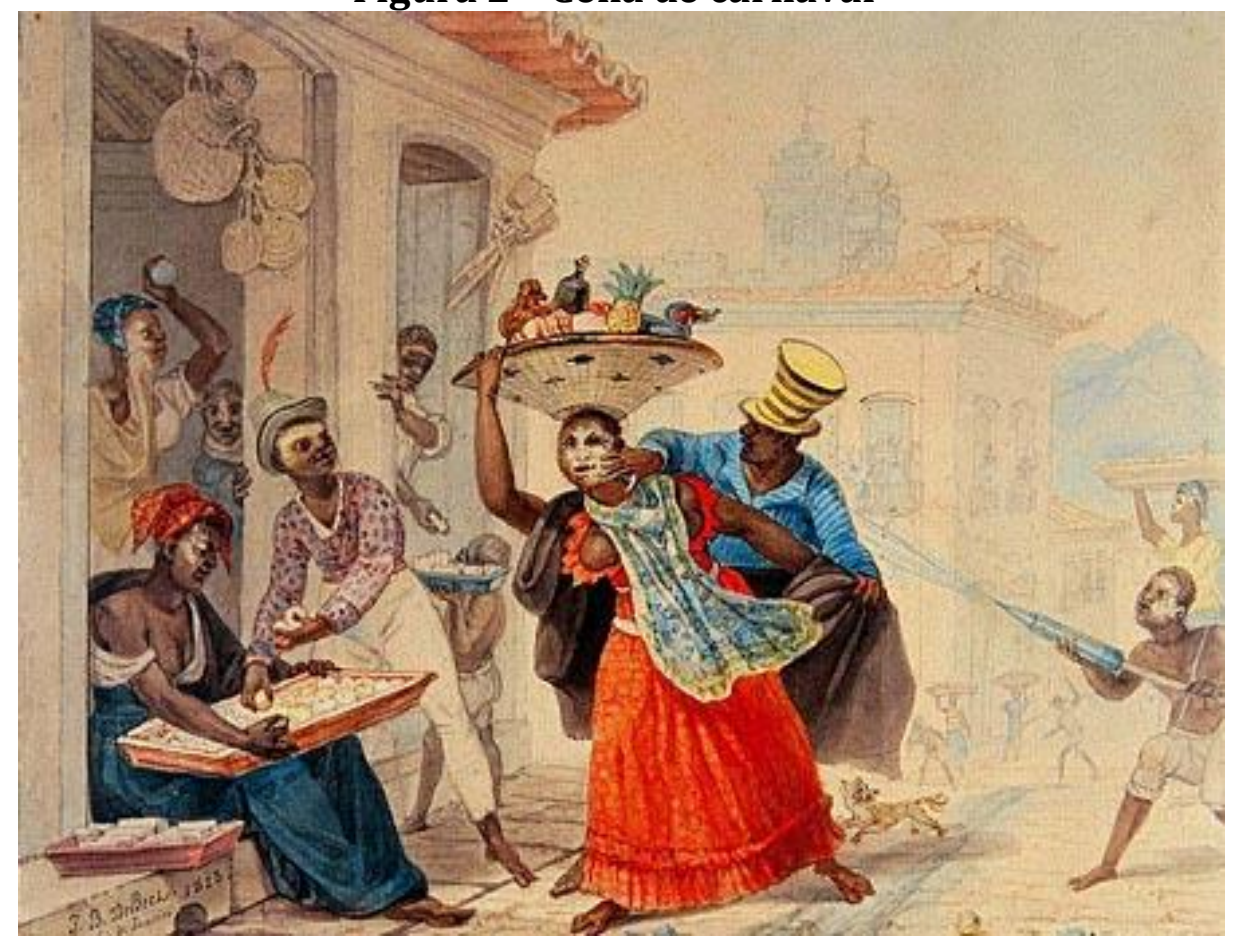

A Figura 2 retrata uma cena típica do carnaval brasileiro do século XIX. Nessa gravura de Debret percebe-se apenas a presença de negros nas ruas do Rio de Janeiro durante os dias de Entrudo.

Também se vê, claramente, na Figura 2, a enorme algazarra daqueles dias. Inclusive, vale a pena chamar a atenção para algumas personagens: mascarados esquivando-se para não serem lambuzados, vendedores e seus tabuleiros repletos de "limões de cheiro", um menino com uma bisnaga jorrando algum tipo de líquido na mulher que lhe arremessa um projétil e, no primeiro plano, a vendedora ambulante que está sendo enfarinhada pelo homem de cartola.

Por conta dessa impetuosidade dos brincantes do Entrudo Popular, inúmeras eram as condenações no período. “0 ideal para as elites brasileiras, seria preservar a festa caseira e dar-se um fim à confusão das ruas". (FERREIRA, 2004, p. 96).

\footnotetext{
2 DEBRET, Jean-Baptiste. Scène de Carnaval. 1835. 1 gravura, litografia pb., 2592 x 3872 pixels, 300 dpi (resolução). Paris: Firmin Didot Frères. Disponível em:

http://www.brasiliana.usp.br/bbd/handle/1918/624520076 Acesso em: 23 set. 2013.
} 
Até se incentivava o uso de bisnagas e limõezinhos de cera dentro das residências, e se censurava a bagunça entrudística das ruas. Todavia, essa censura não era nada fácil, uma vez que boa parte da algazarra era comandada por membros das "boas" famílias que se arriscavam às ruas. Ferreira (2004) cita uma reclamação contra o Entrudo publicada no jornal 0 Carapuceiro, de Recife, em 15 de fevereiro de 1834: "Por que razão imitando as nações mais cultas, não eliminamos o bárbaro e grosseiríssimo divertimento do Entrudo”.

A solução para acabar com o Entrudo poderia estar nas brincadeiras importadas da Europa, sobretudo da França, pela burguesia brasileira e a corte portuguesa. Com a chegada da família real e a instalação da sede do Império Ultramarino Português, em 1808, a cidade do Rio de Janeiro começa um processo de sofisticação bastante acelerado. Os novos habitantes de modo europeu, que vieram com a corte portuguesa, influenciam diretamente nos costumes da colônia.

A França, mais importante centro cultural do ocidente no século XIX, tem um papel protagonista nessa sofisticação dos costumes brasileiros. D. João VI, 1816, faz virem de Paris inúmeros escultores, pintores e arquitetos que passaram a ditar um novo estilo para as artes brasileiras.

Entretanto, eles trouxeram consigo os ideais republicanos de "liberdade, igualdade e fraternidade", que se intensificaram, principalmente, depois da independência do Brasil, em 1822. A partir de então, tudo que representava Portugal era considerado como anacrônico, ultrapassado e, sobretudo, antibrasileiro. Por sua vez, a França representava, para a nova elite brasileira, a modernidade, a liberdade nacional, a vanguarda.

Logo, o Entrudo começava a parecer impróprio para uma nação que buscava se espelhar no modelo cultural francês. Araújo (1996) cita um artigo publicado no Diário de Pernambuco, em 6 de fevereiro de 1837, que reprova veementemente as festas "devassas" do período carnavalesco:

Nós que professamos uma Religião que condena todas as devassidões, que é pura, fundada na moral [...]; nós que pretendemos apurar nossa civilização, e levá-la ao grau das nações cultas, nós devemos porventura caprichar de excessos, de loucura, promover a desmoralização e os crimes, nas turbulências e devassidões das festas de Baco, Saturno e de Flora? Não por certo. ARAÚJO (1996, p. 37) 
A partir dos anos de 1840, os bailes de máscara importados da Europa representavam a nova forma de brincar o carnaval no Brasil, sobretudo, nas principais capitais com Rio de Janeiro, São Paulo, Salvador e Recife.

As autoridades sentiam, cada vez mais, a necessidade de evitar ou, pelo menos, de limitar a participação popular em atividades entrudísticas. Por isso, buscavam incentivar a realização das festividades carnavalescas em lugares específicos. É claro que as brincadeiras do entrudo ainda ocorriam, mas a sociedade das grandes capitais brasileiras passava a dar mais valor a outros tipos de folia, tais como os corsos e os bailes à fantasia. Segundo Ferreira,

\footnotetext{
Havia sociedades compostas não somente de sofisticados burgueses mas também indivíduos das camadas médias da população que, procurando imitar a elite endinheirada, organizavam-se em grupos que repetiam, a seu modo, a forma de desfile dos clubes mais sofisticados (FERREIRA, 2004, p. 207).
}

Isso fez com que houvesse uma verdadeira profusão de clubes, blocos, cordões etc. $\mathrm{O}$ jeito de brincar do povo, até então, chamado de "carnaval pequeno", começava a se misturar à maneira burguesa ou ao "carnaval grande". "A capital do Brasil, possuindo características únicas, manifestas e influenciadas em sua formação espacial e social, reagiria de forma peculiar ao projeto carnavalesco que procurava se impor sobre ela" (idem, p. 220).

Na virada do século XIX para o século XX, o carnaval do Rio de Janeiro já era conhecido internacionalmente e representava aquilo que se concebe como a "alma carioca".

A miscigenação racial e o sincretismo religioso presentes no Rio de Janeiro possibilitaram que novas formas de brincar surgissem, entre elas, destaca-se o samba. Por outro lado, o início do século XX também é marcado pelo enquadramento das novas brincadeiras às regras e parâmetros impostos pelas autoridades. Para Ferreira (2004, p 248), "esses dois caminhos faziam parte de um mesmo processo e negociações que acabariam por resolver e apaziguar as tensões existentes".

Embora o carnaval já fosse visto no Brasil como algo nascido no seio popular e destinado a abrandar, mesmo que temporariamente, o sofrimento do 
povo, a burguesia sempre buscou demonstrar sua influência sobre as festividades momescas.

Esse caráter dual fez com que os grupos de samba advindos dos morros cariocas passassem por um processo gradativo de organização e adequação às normas até se tornarem o que hoje concebemos como "escolas de samba".

Em Recife, também ocorriam os bailes e os passeios à semelhança do que acontecia na capital do Império. Entretanto, tanto na capital pernambucana quanto na capital nacional à época, outras brincadeiras buscavam ocupar o seu lugar no período carnavalesco.

Em 1889, por exemplo, já era fundado o Clube dos Vassourinhas, tradicionalíssima agremiação carnavalesca do carnaval recifense. Ressaltamos que o Vassourinhas era formado, basicamente, por pessoas de baixa renda.

Muitas vezes, os nomes desses grupos faziam menção à profissão de seus membros, tais como o "Carvoeiros" e o "Pescadores do Pontal", ou tinham alguma motivação cômica, a exemplo, do "Viúvas destroçadas".

Esses grupos eram denominados de "clubes de pedestres", justamente, para diferenciá-los dos "clubes de alegorias e críticas", que buscavam assemelhar-se às sociedades carnavalescas do Rio de Janeiro. Segundo Ferreira (2004, p. 381), “A presença de porta-estandarte, pessoas desfilando com sombrinhas coloridas e um grupo fantasiado de morcego abrindo alas são algumas características que os Clubes de Pedestres teriam em comum com os futuros Clubes de Frevo".

Tais grupos se apresentavam acompanhados de uma banda, ao estilo militar, chamada de "cordão", que executava marchas e dobrados para que os componentes do grupo fizessem suas manobras sob a coordenação de um mestrebaliza. Também era comum que esses grupos parassem em locais predeterminados para que seus membros pudessem cantar fados e árias.

Uma suposta origem do frevo é atribuída ao surgimento do Clube de Alegorias e Críticas dos Caraduras, que foi criado em 1901 e desfilava em carros tocando polcas e marchas aceleradas. Suas apresentações atraíam muitos pobres, ex-escravos, capoeiras etc., provocando o que nos anos de 1910 se costumava chamar de "frevedouro". Na opinião de Ferreira (2004, p. 382), 
“'Olha o frevo!' era uma exclamação difundida durante o carnaval, usada tanto para se referir à alegria dos bailes quanto das ruas. Essa terminologia, associada à folia exacerbada, acabaria por dar o nome aos animados grupos e ao novo ritmo da folia do Recife".

Além disso, as maltas de capoeira que se ligavam às bandas de música para rivalizarem com grupos inimigos têm uma relação direta com as origens do ritmo pulsante do frevo pernambucano, visto que é inegável a semelhança dos passos do frevo com os movimentos executados pelos capoeiristas durante um duelo, bem como parece-nos inconteste que a palavra "frevo" tenha surgido a partir de uma corruptela do verbo "ferver".

Veremos na seção a seguir que o maracatu nação ou de baque virado é outra manifestação cultural genuinamente pernambucana e que tem suas origens ligadas aos negros que habitavam a região metropolitana do Recife na passagem do século XIX para o século XX.

\section{Maracatu: conceitos e origens}

O fato de termos nascido e vivido por quase toda vida em Pernambuco, mais precisamente, na cidade de Aliança, que está localizada na Zona da Mata Norte do estado e, por conseguinte, termos vivenciado manifestações da cultura popular daquela região, fez-nos interessar pelo estudo do universo semiótico do maracatu rural, de orquestra ou de baque solto.

Preocupamo-nos, no presente artigo, em resgatar as origens históricas do maracatu. Também sentimos a necessidade, inicialmente, de opormos o maracatu rural, nosso objeto de estudo, ao maracatu nação ou de baque virado, originário da região metropolitana de Recife, mais precisamente, de cidades como Olinda, Igarassu e Itamaracá.

No seu livro Danças Dramáticas do Brasil, Mário de Andrade (1982) afirma que a origem da palavra "maracatu" é muito discutida, entre as várias versões, ele dá destaque àquela que defende uma etimologia ameríndia, o que não é suficiente para encerrarem-se as controvérsias, pois, mesmo assim, haveria duas possibilidades. Na primeira versão, maracatu adviria de "maracá" (instrumento de percussão indígena) e catu (bom, bonito em tupi).

Outra possibilidade seria a palavra ter-se originado de marã (guerra, confusão) e catu, cuja definição fora dada no parágrafo anterior. Nesse segundo 
caso, poderíamos entender maracatu como "guerra bonita", fazendo menção ao sentido guerreiro e festivo comuns ao maracatu.

Para Benjamin (1989), a hipótese de ela ter-se originado a partir da palavra MARACÁ não tem fundamento, ele sugere que talvez ela fosse uma senha criada onomatopaicamente a partir dos sons dos tambores e que era utilizada pelos praticantes para informar da chegada da polícia.

O autor defende que o Maracatu Nação ou de Baque Virado originou-se nas festividades católicas de coroação dos Reis Negros que ocorriam durantes as festas dedicadas a Nossa Senhora do Rosário, que ocorriam, provavelmente entre os séculos XVII e XVIII, em cidades da região metropolitana do Recife, tais como: Olinda, Abreu e Lima, Igarassu, Itamaracá e Itapissuma. Tais reis e rainhas serviam de intermediários entre os poderes coloniais oficialmente instituídos e a comunidade negra da época.

Cascudo (2001) aponta para o fato de existirem documentos que comprovam que tais cerimônias ocorriam desde o século XVII. O autor cita, inclusive, a coroação de Antônio Carvalho e Ângela Ribeira que ocorrera na igreja de Nossa Senhora do Rosário dos Homens Pretos, no ano de 1674.

Na verdade, essa tese de o Maracatu Nação ter sua origem na coroação dos reis e rainhas do congo já era defendida por Pereira da Costa desde o início do século passado. Ele afirmara que "o maracatu é propriamente dito um cortejo régio, que desfila com toda a solenidade inerente a realeza, e revestido, portanto, de galas e opulências" (COSTA, 1908, p. 226). Guerra-Peixe (1980), importante etnomusicólogo e estudioso do maracatu, comenta sobre o consenso sobre as origens do maracatu nação, para ele, "os autores modernos concordam que o Maracatu seja um cortejo real cujas práticas são reminiscências decorrentes das festas de reis negros, eleitos e nomeados na instituição do Rei do Congo" (GUERRAPEIXE, 1980, p. 15). Vale salientar, ainda, que, dentre todas as etnias africanas que habitavam Pernambuco à época apenas as do congo gozavam do direito de eleger o seu Muchino riá Congo, como, segundo Costa (1908), chamavam-no em seu idioma.

Nos dias atuais, a festividade do Maracatu deixou de lado o ritual de coroação, o folguedo manteve apenas o cortejo, mais precisamente o desfile de 
uma corte real inteiramente negra, ficando clara a intenção de se tentar reproduzir o vestuário da corte portuguesa da época da colônia.

Quanto à estrutura, fica clara a referência do modelo processional oriundo do cortejo dos reis negros. Suas personagens são: um rei, uma rainha, um príncipe, uma princesa, duas damas do paço ou da boneca, damas do buquê (a quantidade varia de um maracatu a outro), damas da corte (condutoras das taças), embaixador ou porta-estandarte (vestido à Luis XV), escravo (condutor do pálio), lanceiros (guarda real), baianas (que usam os trajes das filhas de santo), e os pajens, que seguram as caudas dos mantos dos membros da corte.

Figura 3 - Personagens do maracatu nação ${ }^{3}$

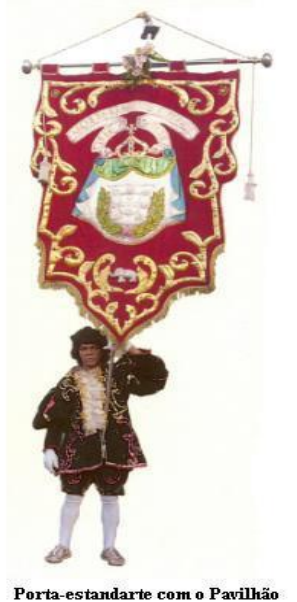

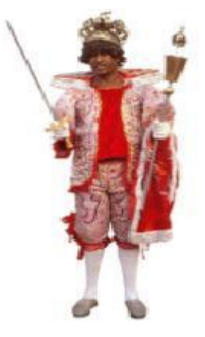

Rei

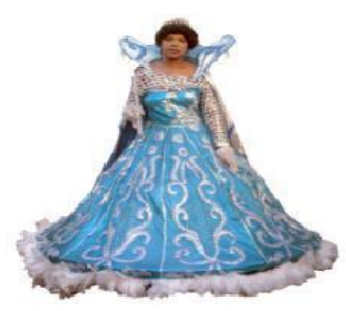

Rainha
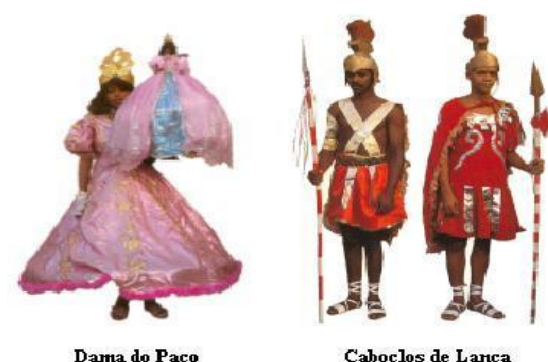

Caboclos de Lança
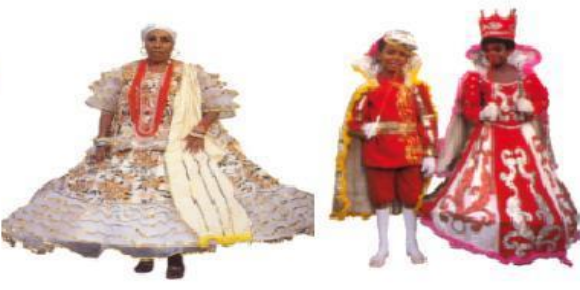

Rei e Rainha Mirins

Por outro lado, a cultura africana se manifesta, indubitavelmente, através da dança e da música do maracatu, pois acompanha o cortejo um grupo musical formado por: gonguês, alfaias (bombos), caixas de guerra, agbês e ganzás.

${ }^{3}$ Disponível em: http://maracatualmirantedoforte.blogspot.com.br, acesso em 05/08/2012. 


\section{Figura 4 - Instrumentos do maracatu nação ${ }^{4}$}

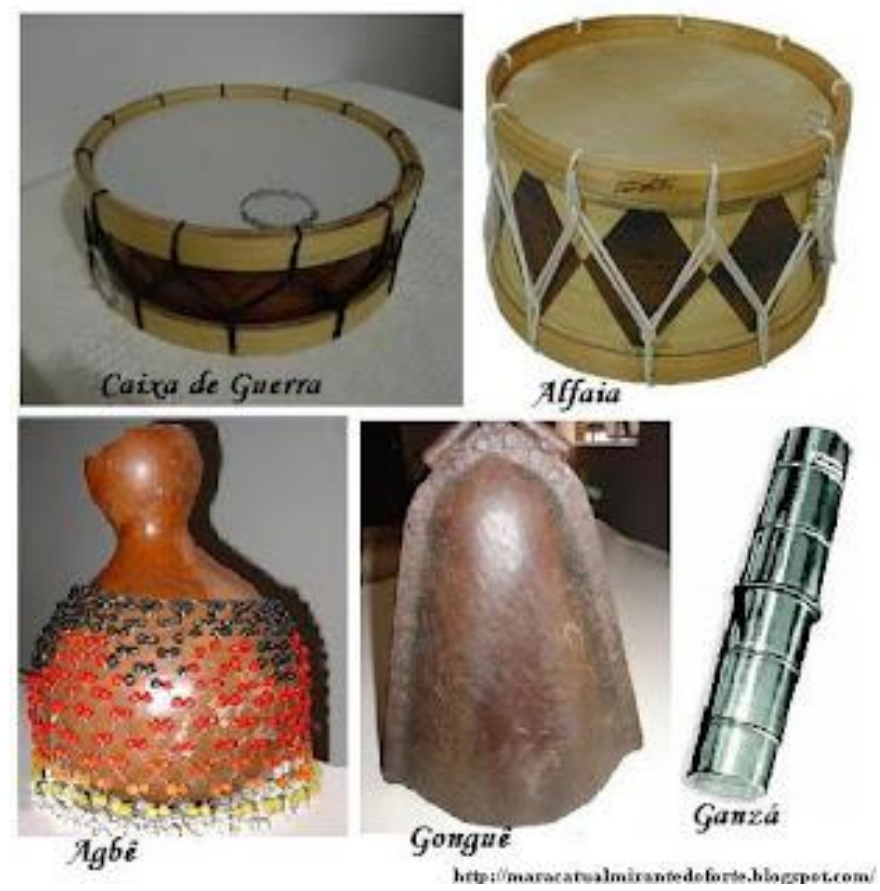

Além disso, a ligação desses grupos com as religiões de matriz africana é muitíssimo forte. Seus praticantes quase sempre são frequentadores de um terreiro e também é muito comum que o posto de rainha seja ocupado pela mãe de santo, a sacerdotisa do grupo.

O maracatu rural, de baque solto ou de orquestra, típica manifestação popular da Zona da Mata Norte de Pernambuco, ter-se-ia originado, segundo Bonald Neto (1991), a partir do Maracatu Nação ou de Baque Virado. Este, por sua vez, seria oriundo das cidades da região metropolitana do Recife, tais como: Olinda, Abreu e Lima, Igarassu, Itamaracá e Itapissuma, onde, provavelmente entre os séculos XVII e XVIII, durante as festas de Nossa Senhora do Rosário, eram coroados os reis e as rainhas do Congo, que serviam de intermediários entre os poderes coloniais oficialmente instituídos e a comunidade negra da época.

Entretanto, há aqueles que, como Câmara Cascudo, defendem outra genealogia para o maracatu rural. Em seu livro Made in Africa, o autor afirma que o cambindas $^{5}$

\footnotetext{
${ }^{4}$ Disponível em: http://maracatualmirantedoforte.blogspot.com.br, acesso em 05/08/2012.
} 
[...] foi a modalidade primitiva dos maracatus de Pernambuco [...], foi sinônimo de escravo africano. Cambindas eram também denominados os grupos dançantes de negros que folgavam pelo Recife em préstito, até a porta da Matriz, depois convergindo, funcionalmente, para o carnaval, no ritmo solene dos desfiles fascinantes dos maracatus [...] Cabinda, cambinda, foi a denominação inicial do maracatu. (CASCUDO, 2001, p.164-165).

Realmente percebemos nítidas semelhanças entre as duas modalidades da manifestação da cultura popular nordestina: no Cambindas, os homens que tomam parte da brincadeira pintam o rosto e travestem-se de mulheres, a exemplo do que ocorre com a Catirina ou Catita no Maracatu. Outro ponto de contato entre elas é a grande recorrência da palavra "cambinda" nos nomes dos maracatus da Zona da Mata pernambucana, inclusive, os dois mais antigos Maracatus Rurais em atividade, o Cambindinha, fundado em 1914, em Araçoiaba; e o Cambinda Brasileira, fundado em 1918, no Engenho Cumbe, em Nazaré da Mata.

Figura 5 - Apresentação de um grupo de cambindas 6

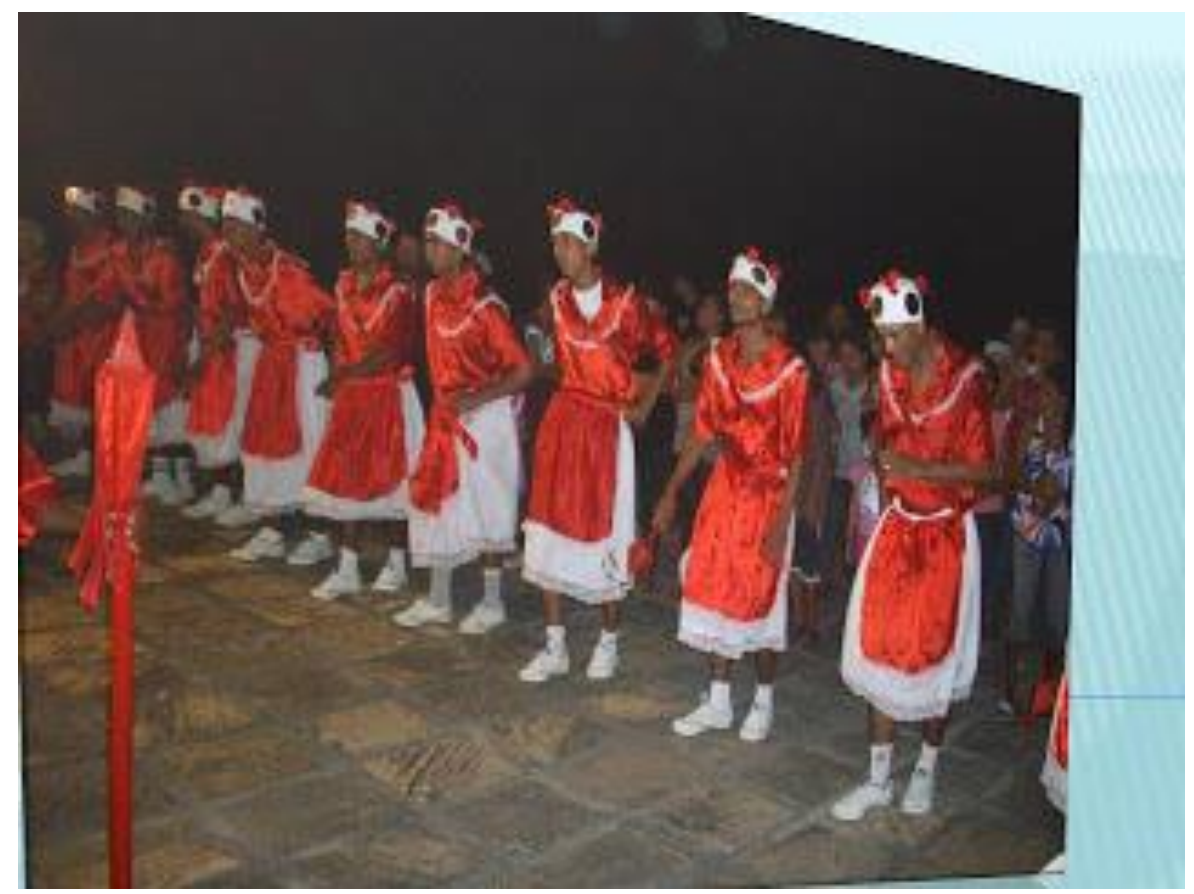

Para Benjamim (1989) ainda existem grupos de cambindas formados apenas por homens nos municípios de Taperoá e Lucena, na Paraíba; e em Ribeirão

\footnotetext{
${ }^{5}$ A palavra vem de Cabinda, região ao Norte de Angola, acima do rio Congo.

${ }^{6}$ Grupo Cambinda Brilhante de Lucena - PB.

Disponível em: http://santuarionossasenhoradaguia.blogspot.com.br/, acesso em 26/08/14.
} 
e Pesqueira, no estado de Pernambuco. Para o autor, também teria existido, há pouco, grupos de cambindas em outras cidades pernambucanas, tais como São Bento do Una, Triunfo, Bonito e Bezerros.

O maracatu rural se originou nos engenhos de cana de açúcar, a maioria de seus brincantes vive até hoje do plantio e do corte da cana. De acordo com Medeiros (2005, p.206), nestes engenhos "existia um forte coronelismo, autoritarismo, cerceamento da liberdade, violência. A disciplina nos engenhos era medieval, cheia de castigos, punições, privações de divergências políticas e religiosas".

O maracatu surge, então, como uma forma de contestação, a revolta dos brincantes transparece na força das coreografias, sobretudo no seu ritmo selvagem, na busca de proteção espiritual, no uso da lança e no conteúdo de protesto de algumas loas.

Com a proximidade do carnaval, os Maracatus se preparam para as apresentações em suas sedes, que ficam muitas vezes na zona rural. Lá fazem reuniões, confeccionam as fantasias e realizam os ensaios, que podem ser de sede ou de barraca ou uma sambada pé-de-parede.

O brinquedo é "ligado ao período carnavalesco, época em que seu sentido social junto à comunidade de origem se torna mais vivo" (VICENTE, 2005, p. 27). Durante o carnaval, o homem simples do campo, muitas vezes explorado pelo dono do engenho, enche-se de orgulho, de alegria, pois durante a "brincadeira" são reis, rainhas, guerreiros etc.

Um momento que merece destaque na brincadeira do maracatu são as sambadas, encontro de dois maracatus, em que seus mestres varam a noite duelando por meio de tiradas poéticas improvisadas. É um momento mágico, até mais esperado do que aquele em que o mestre sobe no palanque e sente-se obrigado a tecer loas às autoridades presentes. Segundo Amorim (2002, p. 66), "é lá, nos embates noturnos, que a verve do poeta faz a plateia delirar". A sambada é a mais autêntica representação da capacidade inventiva do mestre.

Durante as sambadas, tudo é festa, tudo é riso, os mestres constroem suas rimas de forma que seja dada ao outro a possibilidade do revidar. Eles disputam, 
mas riem de si mesmos, bem ao estilo do riso festivo carnavalesco apontado por Bakhtin (1999):

0 riso carnavalesco é em primeiro lugar patrimônio do povo (esse caráter popular, como dissemos, é inerente à própria natureza do carnaval); todos riem, o riso é "geral"; em segundo lugar, é universal, atinge a todas as coisas e pessoas (inclusive as que participam no carnaval), o mundo inteiro parece cômico e é percebido e considerado no seu aspecto jocoso, no seu alegre relativismo; por último, esse riso é ambivalente: alegre e cheio de alvoroço, mas ao mesmo tempo burlador e sarcástico, nega e afirma, amortalha e ressuscita simultaneamente. (p. 10)

Nas sambadas, não se dança com passos ensaiados, coreografados. Na verdade, as pessoas fazem a festa, o "brinquedo", com aquilo que sabem, com aquilo que gostam de fazer, tudo flui dentro do ritmo livre e descontraidamente, bem ao estilo carnavalesco.

0 ritmo a que nos referimos é ditado pela orquestra, que é composta de trombone, trompete, clarinete e do terno composto pelo bombo, surdo, tarol, porca e gonguê. Porém, tal composição pode variar de uma apresentação a outra, acrescentando-se outros instrumentos como o ganzá (mineiro) e o saxofone, ou mesmo retirando alguns dos instrumentos já citados.

0 mestre é quem conduz as apresentações, porém, todas as personagens do Maracatu possuem fundamental importância na constituição desse espetáculo festivo. 0 mestre é a alma da agremiação, um bom maracatu deve ter, antes de tudo, um ótimo mestre. Através de seu apito e de sua bengala, ele comanda a brincadeira e a movimentação do maracatu durante o espetáculo.

As baianas seguram os emblemas da agremiação, e aquela chamada de dama da boneca ou dama do passo tem também a responsabilidade de conduzir a Calunga, divindade que trará proteção ao grupo. Sua origem está ligada aos cultos afro-brasileiros, sendo um dos elementos comuns aos maracatus de baque solto (rural) e de baque virado ou nação, mais comuns na região metropolitana de Recife.

A calunga ou boneca é um elemento totêmico, sagrado, que representa a entidade espiritual protetora do maracatu. Durante o cortejo, a boneca segue protegida por todos os integrantes da agremiação. Em quimbundo, língua originária de Angola, calunga é o plural de lunga ou malunga. Daí a explicação para 
o vocábulo Malunguinho, que representa não a boneca, mas a própria entidade espiritual.

Real (1990) destaca que dentro da Jurema, ritual de origem indígena, vulgarmente chamado de catimbó, e que é praticado pelos membros do Maracatu, há uma entidade chamada Malunguinho, nome pelo qual eram chamados os quilombolas que habitavam a região. Uma curiosidade é que "malunguinho", na Zona da Mata de Pernambuco, também nomeia a fuligem originada pela queima da palha da cana de açúcar.

Em homenagem à Calunga, na saída dos maracatus, são tiradas as primeiras loas. Nesse momento, ela é retirada do altar pela dama da boneca, passa às mãos da rainha, daí à baiana mais próxima e segue de mão em mão até retornar à sua condutora. É importante lembrar que o maracatu não pode sair de sua sede sem a calunga, responsável pela proteção do grupo.

Os caboclos de lança, guerreiros do maracatu, são os que mais chamam a atenção, justamente por sua quantidade, pela beleza das fantasias e pelas evoluções que executam em torno da corte e dos outros membros do maracatu, a quem devem proteger. Esses caboclos fazem suas evoluções em um círculo externo golpeando o ar com suas lanças, de um lado para o outro.

\section{Figura 6 - Disposição espacial do maracatu rural ${ }^{7}$}

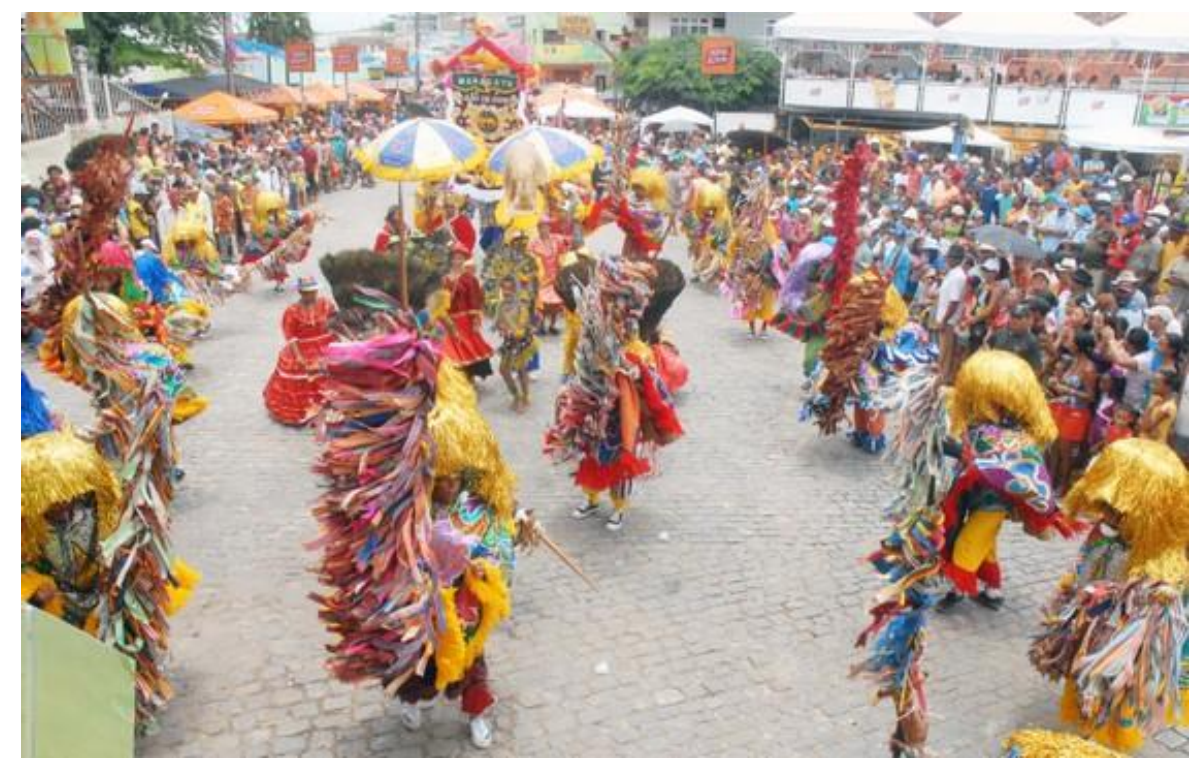

\footnotetext{
${ }^{7}$ Disponível em: http://rasgue.zip.net/arch2009-12-27 2010-01-02.html, acesso em 10/05/12.
} 
Em um círculo menor, ficam as baianas e as damas de buquê. Enquanto, no centro, estão a corte, os caboclos de pena e o estandarte, porém este último também pode vir na frente da agremiação. 0 arrea-má ou caboclo de pena, que quer dizer "o que tira o mal", é uma figura representativa do catimbó e é um dos responsáveis pela proteção espiritual da agremiação também se posiciona mais ao cento, próximo à corte.

\section{Figura 7 - Corte do maracatu 8}

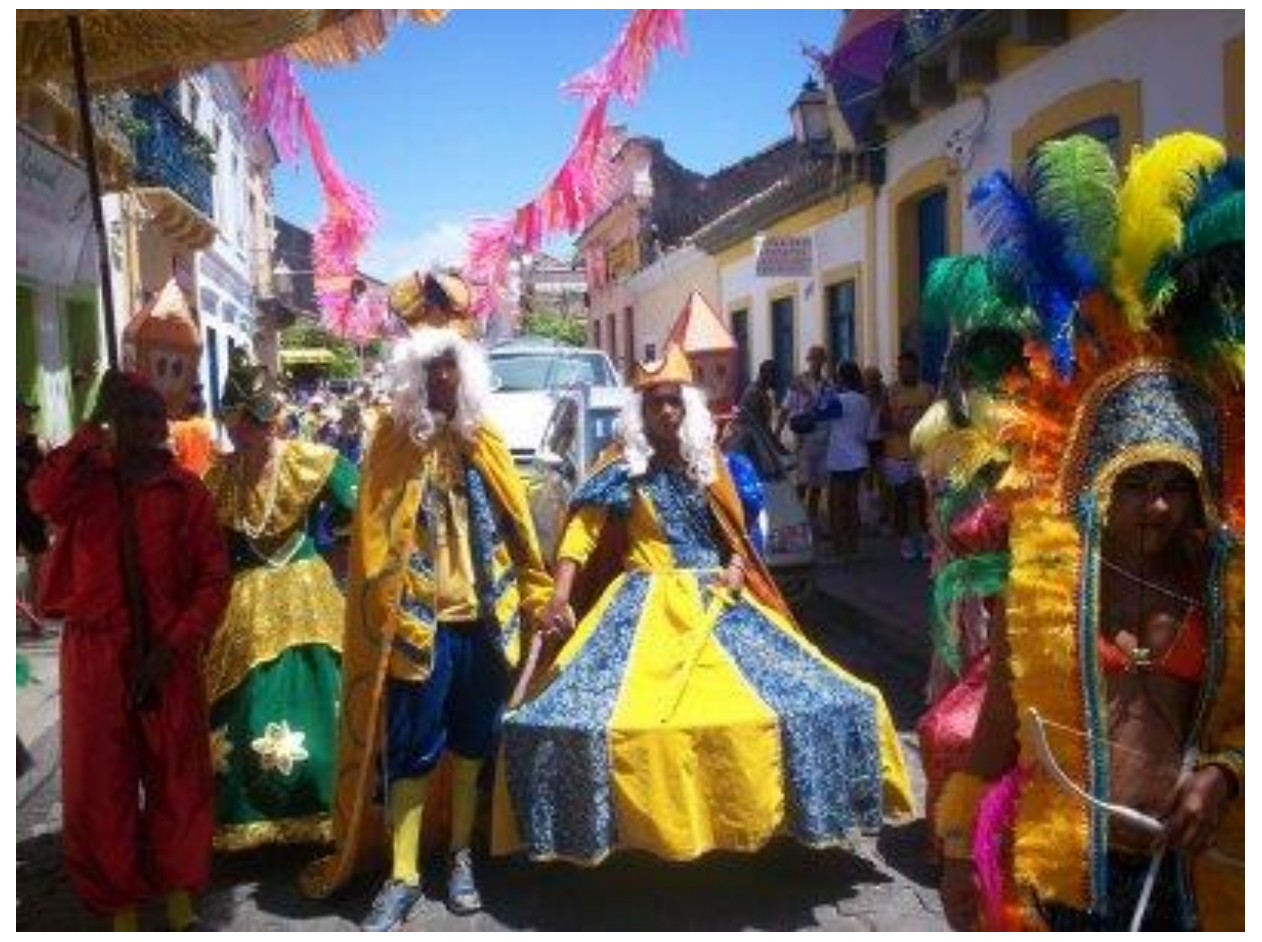

Ainda a respeito do Caboclo de lança, fascinante personagem do maracatu rural, é importante frisarmos que também há uma grande discussão sobre sua origem. Bonald Neto (1991) acredita que ele simbolizaria os filhos de Ogum, que, no sincretismo religioso, representariam São Jorge. Daí adviria o fato de os caboclos, em respeito a essas divindades, não poderem tomar banho e praticarem abstinência sexual no período que vai da sexta-feira de carnaval à quarta-feira de cinzas.

\footnotetext{
8 Disponível em: http://rasgue.zip.net, acesso em 10/05/12.
} 
Figura 8 - Caboclos em um terreiro de um umbanda. ${ }^{9}$

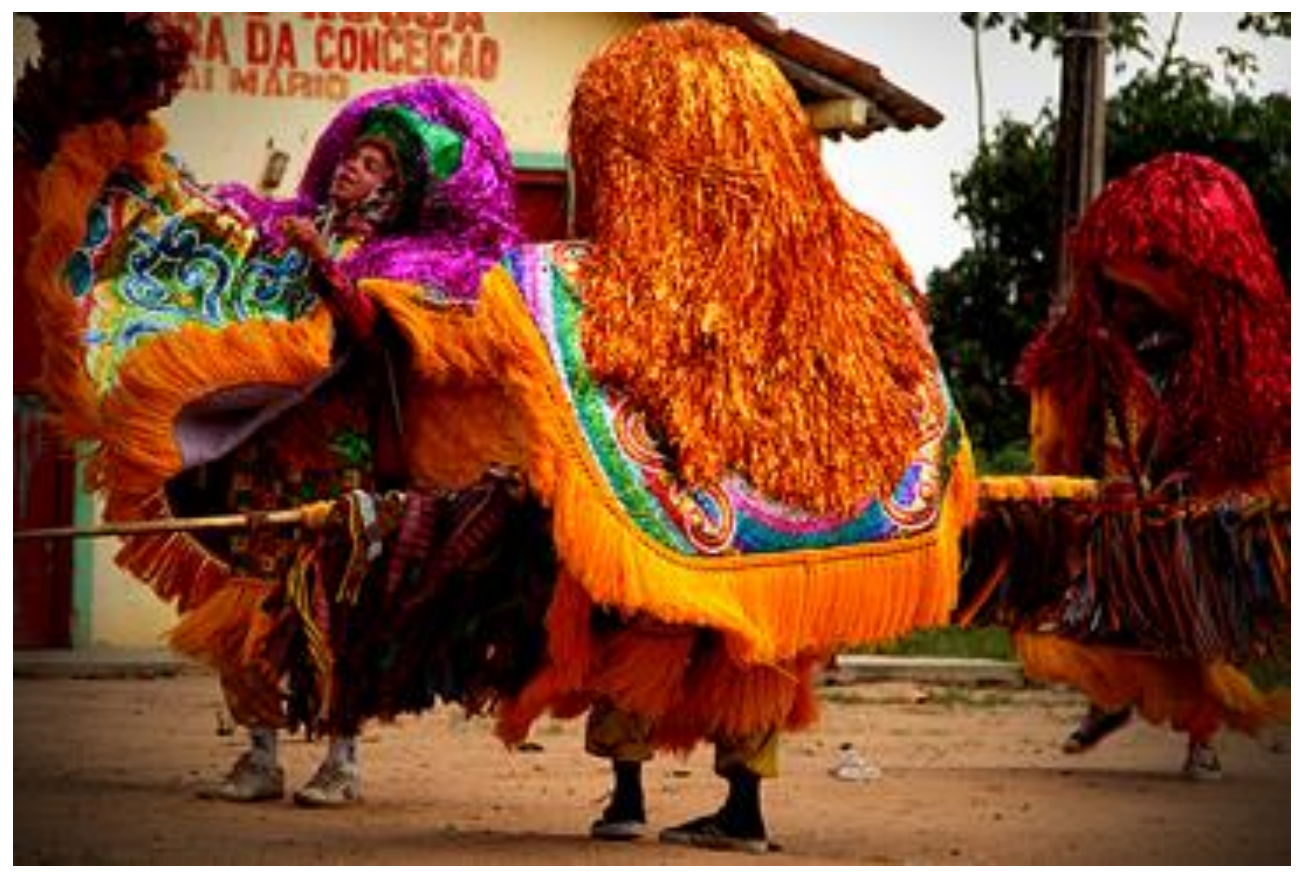

A Figura 8 ilustra bem este sincretismo religioso presente no maracatu rural. Na foto, dois caboclos do Maracatu Rural Estrela de Ouro de Aliança estão fazendo suas evoluções no terreiro de umbanda do Pai Mário que fica ao lado da sede do maracatu.

É importante frisar também que o Pai Mário, além de conselheiro espiritual do maracatu, também é o rei nas apresentações do Estrela do Ouro. Além disso, na inscrição na parede da casa lemos - além do nome do pai Mário -, o nome Nossa Senhora da Conceição, que nos cultos de matriz africana está relacionada à Iemanjá.

Já Benjamim (1989, p. 202) defende que "o lanceiro é a mesma figura do 'Mateus', presente no bumba meu boi, com um progressivo enriquecimento dos motivos decorativos e mudança de papel". Outra personagem do Maracatu que aparece no bumba meu boi e serve para autenticar esse ponto de vista é a Catirina, que representa, em muitos bois, a mulher do Mateus.

\footnotetext{
${ }^{9}$ Disponível em:

http://especiais.jconline.ne10.uol.com.br/pernambucovivo/img/personagens/destaque/estrelade-ouro.jpg, acesso em: 07/05/2015.
} 
Figura 9 - Dança dos caboclos de lança ${ }^{10}$

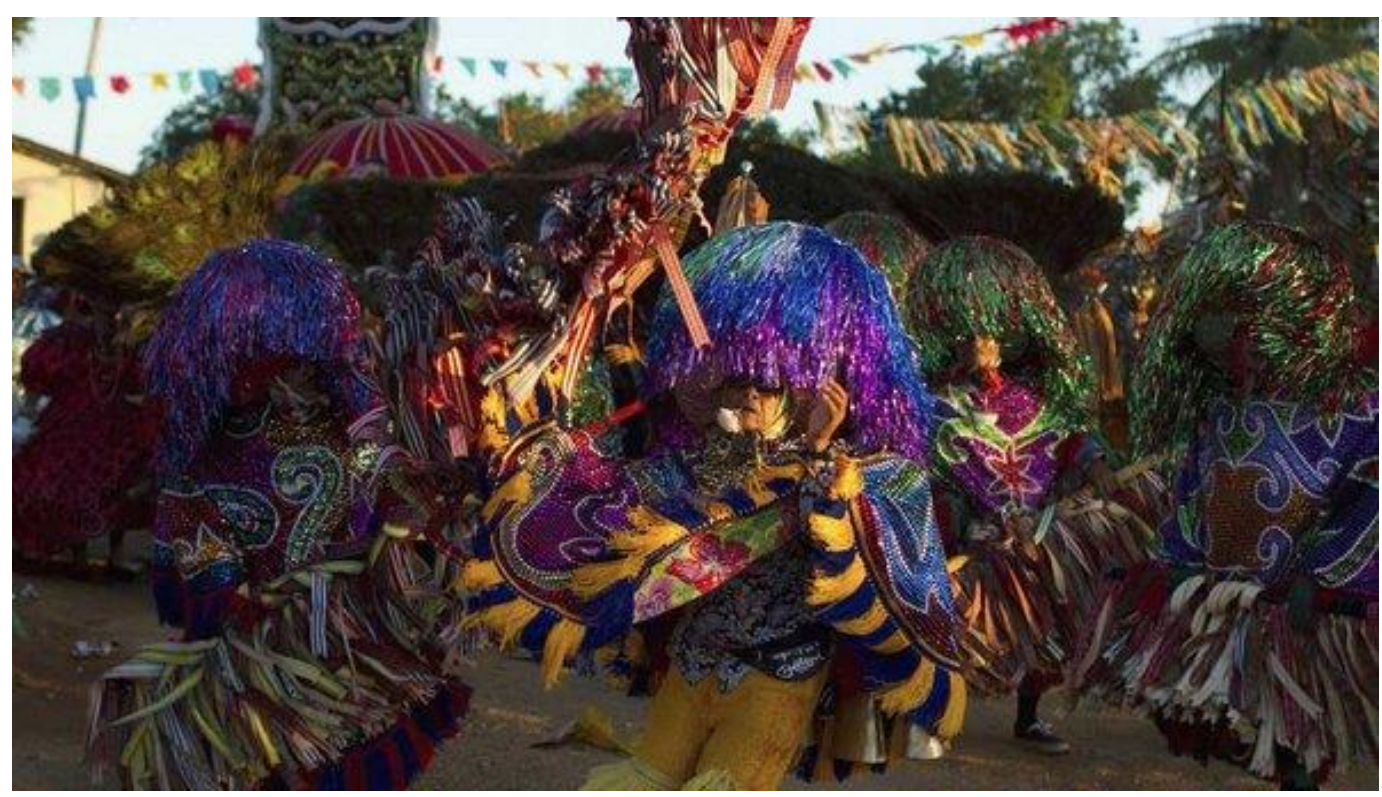

Katarina Real assenta-se como defensora de outra tese sobre a origem dos caboclos de lança, ao estabelecer uma relação entre a região em que surgiram os caboclos e os antigos quilombos da Zona da Mata Norte pernambucana. Para a antropóloga:

Esses lanceiros possivelmente sejam descendentes, legítimos ou pelo menos socioculturais, do antigo Quilombo de Catucá ou de outros Quilombos existentes nas redondezas de Goiana no século passado. (REAL, 1990, p. 188)

Na verdade, ficam nítidas as múltiplas influências recebidas pelo Maracatu de Baque Solto, o que torna inviável precisarmos uma única origem. Há nele uma verdadeira fusão de elementos de diversos folguedos nordestinos.

O caboclo de lança hoje se tornou uns dos principais símbolos do carnaval de Pernambuco, mas nem sempre foi assim. As elites culturais dos grandes centros urbanos pouco se interessavam pelo estudo de manifestações culturais advindas das camadas mais populares, sobretudo, aquelas representativas das populações rurais.

${ }^{10}$ Disponível em: http://veja.abril.com.br/multimidia/galeria-fotos/a-tradicao-do-maracatu-no-interiorpernambucano. Acesso em: 10/05/2012. 
Tal desconhecimento se torna latente na afirmação de Bonald Neto sobre a figura do caboclo de lança:

Eis a mais exótica e ainda desconhecida figura do mundo maravilhoso e armorial que anda pelas ladeiras olindenses e pelos montes dos arrabaldes do Recife com suas cores, seus chocalhos e suas fitas flutuando nos ares, a recordar engenhos e canaviais (BONALD NETO, 1991, p. 289).

O autor não só assume o desconhecimento como também não busca estabelecer a relação que os caboclos de lança têm com personagens de outras manifestações populares como o Mateus, presente no auto natalino do cavalomarinho, uma vez que ele defende que os maracatus rurais têm sua origem ligada, estritamente, aos maracatus nação da região metropolitana de Recife.

\section{Considerações Finais}

O Maracatu de Orquestra ainda vem transformando-se e absorvendo influências provenientes de manifestações culturais populares, tanto do espaço rural quanto do urbano. Pois, embora seja uma manifestação típica dos engenhos de cana-de-açúcar da Zona da Mata de Pernambuco, suas agremiações viajam para vários estados do Nordeste e até mesmo para fora da região.

Logo, não se concebe estudar o maracatu rural sem tentar dimensionar as influências recebidas de outras culturas, sobretudo da cultura de massa tão presente nos grandes centros urbanos em que os maracatus se apresentam.

Independentemente de sua origem, o maracatu rural é hoje uma das mais representativas manifestações do povo da Zona da Mata de Pernambuco. Suas apresentações levam milhares de pessoas às ruas de cidades como Aliança, Nazaré da Mata, Tracunhaém, Vicência, Goiana, Timbaúba, Carpina, Ferreiros, Itambé, Macaparana, Lagoa do Carro, Lagoa de Itaenga, Buenos Aires, Camutanga, Condado, Itaquitinga, Araçoiaba e Limoeiro.

Por isso, defendemos que o maracatu rural não pode ser concebido como uma variante do maracatu nação, mas como produto de uma complexa combinação de fatores. Sua dança, sua música, seus atores, seus temas e figuras utilizados são representativos de um riquíssimo amálgama das mais diversas manifestações culturais pernambucanas. Nele, encontramos elementos do maracatu nação, do 
frevo, do bumba meu boi, do cavalo-marinho, do catimbó, do catolicismo popular, do cambinda etc. e é, justamente, este sincretismo que o torna atraente aos olhos do público que nele se descobre e reconhece sua luta cotidiana, suas histórias de vida, sua própria alegria de viver. Apesar ser um amálgama de várias culturas, podemos considerá-lo como representativo da cultura popular do Estado de Pernambuco porque foi aqui o lugar de encontro e de aceitação das culturas diversas que o constituíram e promovem a cada ano seu retorno monumental para alegria de todos

\section{Referências}

AMORIM, Maria Alice. Improvisos: uma pisa de rima. In: AMORIM, Maria Alice; BENJAMIN, Roberto. Carnaval: cortejos e improvisos. Recife: Fundação de Cultura Cidade do Recife, 2002. Coleção Malungo; v. 5. p. 61-123.

ARAÚJO, Rita de Cássia. Festas: máscaras do tempo: entrudo, mascarada e frevo no carnaval do Recife. Recife: Fundação de Cultura Cidade do Recife, 1996. 423p.; il.

BAKHTIN, Mikhail. A cultura popular na idade média e no renascimento. Tradução de Yara Frateschi Vieira. São Paulo: Hucitec; Brasília: Editora universitária de Brasília, 1999, 4ª ed.

BONALD NETO, Olimpio. Os caboclos de lança - azougados guerreiros de Ogum. In: SOUTO MAIOR, Mário; SILVA, Leonardo Dantas. Antologia do Carnaval do Recife. Recife: Fundaj, Ed. Massangana, 1991. p. 279-295.

BENJAMIN, Roberto. Folguedos e danças de Pernambuco. Recife: Fundação de Cultura Cidade do Recife, 1989.

CASCUDO, Luís da Câmara. Made in Africa (pesquisas e notas). 5 ed. São Paulo: Global, 2001.

COSTA, Pereira. Folk-lore pernambucano: subsídios para a história da poesia popular e Pernambuco. Recife: Arquivo Público Estadual, 1ạ edição,1908.

FERREIRA, Felipe. O livro de ouro do carnaval brasileiro. Rio de Janeiro: Ediouro, 2004.

GUERRA-PEIXE. César. Maracatus do Recife. Recife: Prefeitura da Cidade do Recife/Irmãos Vitale, 1980.

KOSTER, Henry. Viagens ao Nordeste do Brasil. Tradução e notas de Luiz da Câmara Cascudo. 2a ed. São Paulo: Companhia Editora Nacional, 1942.

MEDEIROS, Roseana Borges de. Maracatu Rural: luta de classes ou espetáculo?. Recife: Fundação de Cultura Cidade do Recife, 2005.

QUEIROZ, Maria Isaura Pereira. Carnaval brasileiro: o vivido e o mito. São Paulo: Brasiliense, 1992. 
RASTIER, François. Semiótica das Culturas e cosmopolitismo in BATISTA, Maria de Fátima B. de M. e RASTIER, François (Orgs). Semiótica e Cultura: dos discursos aos universos construídos. João Pessoa: Editora Universitária, 2015.

REAL, Katarina. 0 folclore do carnaval do Recife. 2 ed. Recife: Fundaj, Massangana, 1990.

SILVA, Leonardo Dantas. Histórias do Carnaval Parte I - Ensaios de Carnaval. Recife: Diário Oficial do Estado de Pernambuco, Ano X, Suplemento Cultural, 1997.

VICENTE, Ana Valéria. Maracatu Rural - 0 espetáculo como espaço social: um estudo sobre a valorização do popular através da mídia e da imprensa. Recife: Associação Reviva, 2005. 